\title{
Læselog som middel til dybdelæring
}

\author{
Lisbeth Lunde Frederiksen, ph.d., lektor i didaktik og padagogik, VIA University College.
}

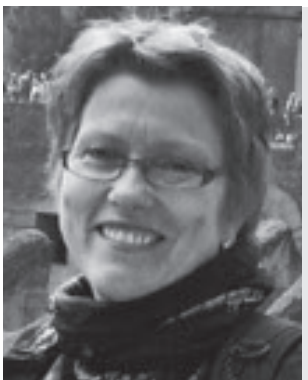

Lisbeth Lunde Frederiksen er ph.d. i uddannelsesforskning. lektor i didaktik og pædagogik ved VIA University College, læreruddannelsen i Århus. Programkoordinator for forskningsprogrammerne Professionsdidaktik og Samspil mellem profession og uddannelse under Videncenter for Skole og Institutionsstuder VIAUC. Forsker derudover i fastholdelse af lærere og vitalisering i lærerarbejdet, står endvidere for dimittendundersøgelserne ved læreruddannelsen i Århus. Har været ansat som ekstern lektor på Syddansk Universitet i universitetspædagogik.

\section{Reviewet artikel}

Denne artikel handler om laseloggen som et padagogisk redskab til at facilitere dybdegående laringsstrategi, kreativ forståelse, distribueret kognition og som udgangspunkt for en reel dialogisk aktiverende undervisning.

Argumentationen baseres på konstruktivistisk laringsteori $i$ et sociokulturelt perspektiv og på Ramsdens teori om overfladestrategi og dybdestrategi i tilegnelse af fagligt stof.

\section{Indledning}

Som underviser på en videregående uddannelse ønsker jeg at medvirke til, at de studerende udvikler intellektuelle evner, som gør dem i stand til at kombinere og relatere tanker og begreber og anvende dem på verden udenfor. Jeg vil gerne medvirke til, at de studerende udvikler evner til at anskue faglige problemstillinger ud fra forskellige perspektiver, og at de bliver i stand til kritisk at analysere teorier, ideer og problemer for på baggrund af dette at være i stand til at kunne tage kvalificeret stilling.

For at de studerende skal kunne opnå dette, må der være kvalitet i deres læring. Om der er kvalitet i læringen er bl.a. afhængig af, hvilken læringsstrategi de studerende benytter sig af (Ramsden, 1999; Biggs, 2003).

Ifølge Biggs arbejder mange af de studerende overfladisk med det faglige stof (Biggs, 2003). Det betyder store udfordringer for underviseren med hensyn til at tilrettelægge undervisning, der kan bidrage til, at de studerende vælger eller lærer at gå i dybden med et stof.

I denne artikel vil jeg præsentere læseloggen som et pædagogisk redskab til at arbejde med disse udfordringer.Jeg vil præsentere læseloggen som et muligt middel for den studerende til at bruge og lære dybdegående læringsstrategi og som en mulighed for at etablere en reel dialogisk og aktiverende undervisning baseret på studenterindsats og i den forbindelse skitsere de bagvedliggende læringsteoretiske tanker.

\section{Hvad er en læselog}

En læselog kan ses som et studieteknisk redskab, der kan bruges til at uddrage et personligt meningsindhold i forhold til akademiske tekster.

Læseloggen kommer egentlig fra folkeskolens danskundervisning og lanceres bl.a. af Birte Sørensen i bogen Litteratur - forståelse og fortolkning (Sørensen, 2001), hvor Sørensen har fokus på elevernes erkendelsesproces og teksten som en erkendelsesproces. Inspireret heraf har jeg gennem min praksis udviklet læseloggen til brug $\mathrm{i}$ videregående uddannelse.

Konkret består læseloggen af et tospaltet $\mathrm{A} 4 \mathrm{pa}-$ pir.Venstre spalte udgør et såkaldt resuméfelt og højre spalte et perspektiveringsfelt.

I resuméfeltet stilles der krav om, at feltet indledes med tekstens konklusion og/eller hovedbudskaber. Derefter følger den læste teksts nøglebegreber og nøglebegrundelser samt vigtige tekststeder.

Perspektiveringsfeltet følger resuméfeltet i dokumentets højre side, men hvor resuméfeltet har fokus på selve teksten, har perspektiveringsfeltet fokus på at få etableret et personligt meningsforhold til teksten.

Her relaterer den studerende teksten til allerede erkendt, indoptaget viden og problemstillinger fra tidligere læste tekster og anden undervisning og sætter den aktuelle teksts tankegang i forbindelse med tanker og teorier $\mathrm{i}$ andre fag/discipliner, hvis det er muligt. Ligeledes er det i perspektiveringsfeltet, at den studerende knytter hverdagens erfaringer til teksten og forsøger at forbinde teksten til den virkelige verden. I dette felt noteres også de personlige tanker, tekstens 


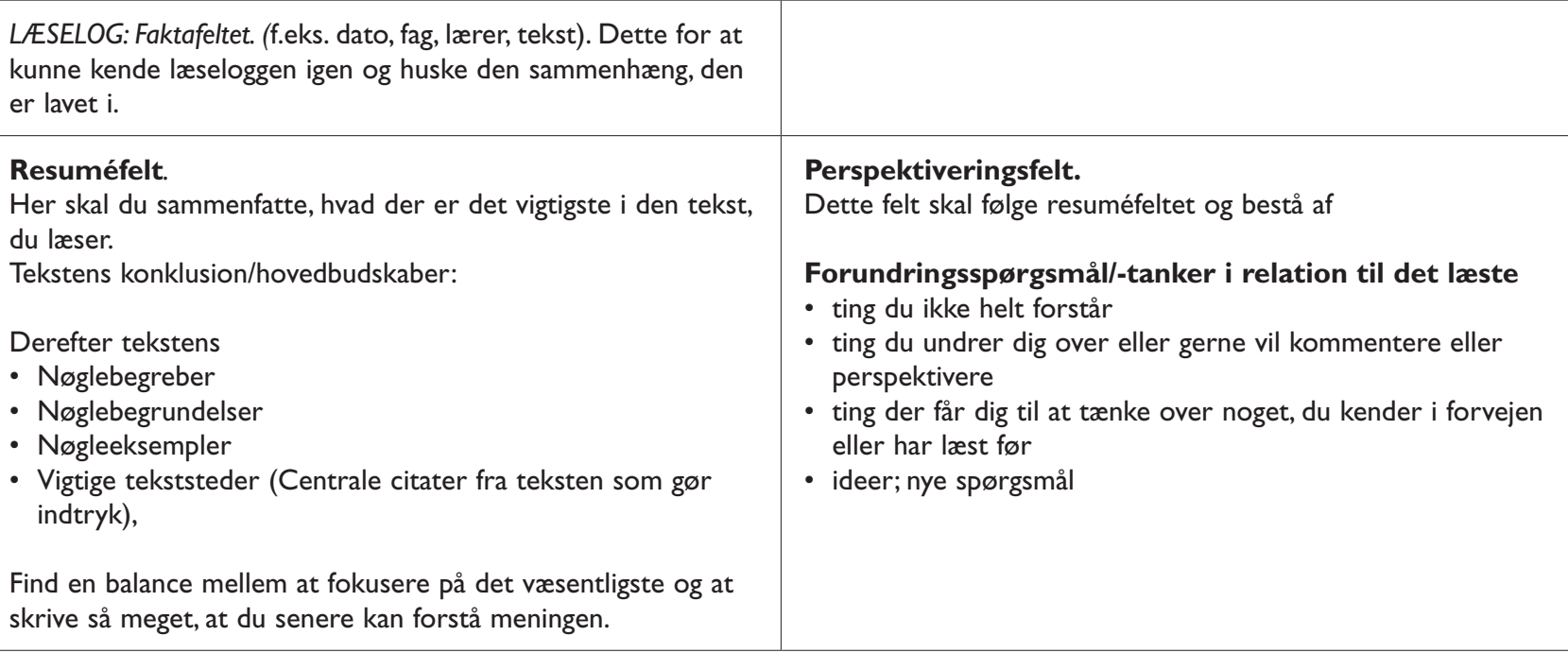

teoretiske pointer giver anledning til, både mht. kritisk stillingtagen, undren og manglende forståelse.

\section{Konstruktivistisk læring med et sociokulturelt perspektiv}

Moderne læringsteorier betragter erkendelsesprocessen som en konstruktionsproces bl.a. pga. det fælles udgangspunkt, at verden ikke kan betragtes om adskilt fra den menneskelige erkendelse (Rasmussen, 2004, s. 200).

Konstruktivismeteorierne kan hovedsageligt opdeles $i$ to varianter. En variant, der er inspireret af virksomhedsteori (Vygotskytraditionen) og en variant, der er præget af fænomenologien og Piagets epistemologi. Varianter, som jeg dog ikke vil gå i dybden med i denne artikel.

Ifølge en konstruktivistisk tankegang opfattes læring som en aktiv konstruktionsproces ud fra et samspil mellem individ og omverden og ikke blot som en passiv modtagelse af information udefra. Forståelsen bliver konstitueret i mødet mellem det, individet allerede ved og kan og det nye. Individet modtager information, tolker den, knytter den sammen med allerede erkendt viden og reorganiserer de mentale strukturer, hvis det er nødvendigt for at indpasse den ny viden (Illeris, 2006, s. 47 ff; 71 ff; Rasmussen, 2004, s. 201 ff.).

Yderligere pointererVygotskytraditionen (den kulturhistoriske tradition), at der er en tæet relation mellem sprog og tænkning, altså at bevidstheden og tænkningen står i tæet relation til sproget (Vygotsky, 1997; 2001).

Når et sociokulturelt perspektiv inddrages i forhold til konstruktivistiske læringsteorier, sættes der ydermere fokus på, at læring har med relationer mellem mennesker at gøre og dermed fokus på kontekst og interaktion. Læring ses her som grundlæggende social, hvorfor interaktionen mellem deltagere $i$ et fællesskab, i dette perspektiv vil være afgørende for, både hvad der bliver lært og hvordan. Individuel læring kan og vil selvfølgelig være mere eller mindre socialt me- dieret, men deltagelse og samspil i et sociokulturelt perspektiv er centrale begreber i forståelsen af læring. Kundskab tænkes konstrueret gennem interaktion og i en kontekst, hvilket betyder at sprog og kommunikation naturligvis vil komme i centrum. Ud fra et sociokulturelt perspektiv på konstruktivistisk læring vil læring ydermere blive forstået som distribueret mellem deltagere $i$ et fællesskab; deltagerne kan og ved noget forskelligt, og deres forskellige bidrag er væsentlige for en helhedsforståelse (Dysthe, 2003; Illeris, 2006, s. $127 \mathrm{ff}$.).

Ud fra dette perspektiv er det vigtigt for læreprocessen at kunne formulere en faglig forståelse i ord, dele den med andre med henblik på én eller anden form for respons og dermed kunne drøfte såvel det, man forstår som det, man ikke forstår. Sproget kan i denne sammenhæng ses som en åbning eller kobling mellem det indre og det ydre; mellem tænkningen og kommunikationen med andre.

Olga Dysthe (Dysthe, 2003, s.54) skriver med henvisning til Säljö, at »Sproget på én og samme tid [er] et kollektivt, interaktivt og individuelt sociokulturelt redskab. Det er derfor, det kan fungere som en kede mellem kultur og interaktion og individets tonkning. "Hun skriver senere med henvisning til Bakhtins forståelse af kommunikation: at "Al kommunikation er (ifolge ham) grundlaggende dialogisk, hvilket vil sige, at forståelse og betydning opstår som et samarbejde mellem den, der taler og den, der lytter, mellem den, der skriver og den, der loser." (s.55)

\section{Bakhtin og dialogen}

Som ovenstående citat af Dysthe viser, er livet ifølge Bakhtin dialogisk i sin natur. Det at leve betyder at være i uafbrudt dialog med andre. Bakhtin mener, at man kun kan nå til bevidsthed om sig selv gennem andre, gennem kommunikation.

Ifølge Bakhtin sker læring altid i interaktion, og dialogen er væsentlig $i$ en personlig tilegnelse af stof. 
Dialogen faciliterer konstruktionsprocesser i forhold til allerede erfaret og konstrueret viden. Dialogen personliggør indholdet, og igennem dialogen konstitueres meningen (Dysthe, 1995; 2003). For Bakhtin handler dialog ikke kun om dialog mellem levende, tilstedeværende stemmer. Begrebet må forstås bredere f.eks. som dialog mellem et individ og læste eller hørte tekster

I dialogen sker der en spænding mellem individet og 'den anden' og lige netop denne spænding mellem forskellige perspektiver, erfaringer og værdier giver individet mulighed for at finde sin egen stemme eller gøre ordet til sit eget indre overbevisende ord. Hermed skabes der mulighed for nye fortolkninger og for helt nye forståelser, forskellige fra 'stemmerne' før dialogen. Der kan herigennem opstå det, Bakhtin kalder for en 'kreativ forståelse', hvormed man skal forstå: En dybere måde at forstå et begreb eller fænomen på, dét at opdage nye sider og nye betydninger ved et begreb eller et fænomen. Interaktion, respons og gensidighed bidrager til en sådan kreativ forståelse (Dysthe, 2003, s. 18 ff.).

\section{Undervisning og autoritative diskurser}

I en undervisning vil der altid på visse tidspunkter være forskellige former for autoritative diskurser med monologiske udtryksformer, der udelukker dialog, kræver entydig accept og ikke giver plads til refleksion, tvivl eller modforestillinger.

Ifølge Bakhtin vil det betyde udelukkelse af kreativ forståelse eller manglende personlig tilegnelse af et stof. Dette behøver dog, ifølge Olga Dysthe, ikke at være tilfældet. I sin bog Det flerstemmige klasserum ${ }^{1}$, pointerer Dysthe, at det essentielle ikke umiddelbart er, om undervisningen har autoritative diskurser men derimod, om disse autoritative diskurser behandles dialogisk, således at den lærende făr mulighed for en personlig tilegnelse af stoffet (Dysthe, 1995).

En mulig vej for at behandle et stof dialogisk også $i$ en undervisning med autoritative diskurser kunne være at benytte læselog som pædagogisk redskab. Den studerende kan gennem brug af læselog få mulighed for at komme i dialog med såvel tekster som reelle levende stemmer/personer. En dialog der kan åbne op for såvel fundamental forståelse og kreativ forståelse af et indhold og give den studerende mulighed for at finde sit eget ståsted i forhold til et indhold.

\section{Overfladestrategi og dybdestrategi}

Ifølge Ramsden (1999) er den måde, et individ bærer sig ad med at lære på, afhængig af den relation, individet har til stoffet. Hvordan man lærer stoffet er afhængig af den måde, individet oplever og organiserer det faglige stof og tillægger stoffet mening; ja, er ' $i$ dialog.' med stoffet.

I forhold til at læse akademiske tekster betyder det, at de studerende overordnet kan gå til tekster på to for- skellige måder: Én der faciliterer dybdelæring(dybdestrategi) og én, der kun bidrager til overfladisk læring (overfladestrategi).

Dybdestrategien er ifølge Ramsden (1999) karakteriseret ved, at den studerende både har viljen til at forstå og fastholde opgavens struktur. Den studerende har ved brug af denne strategi fokus på tekstens konklusioner og søger efter en idé med teksten, altså forfatterens hensigt med teksten. Studerende der benytter sig af denne strategi:

- „fokuserer på, 'hvad der betegnes'(dvs. forfatterens ræsonnement eller de begreber, der er relevante for at løse problemet).

- relaterer tidligere erhvervet viden til ny viden.

Relaterer viden fra forskellige undervisningsmoduler til hinanden.

- relaterer teoretiske forestillinger til hverdagens erfaringer.

- relaterer materiale og argumenter til hinanden og skelner mellem dem.

- organiserer og strukturerer indhold i et sammenhængende hele." ... [her er tale om en] ... Indre vægtning: "Et vindue, gennem hvilke aspekter af virkeligheden bliver synlige og mere forståelse' (Entwistle og Marton, 1984)«(Ramsden, 1999 s. 64)

Ved dybdestrategien forsøger den studerende således at uddrage et personligt meningsindhold af artiklen. Den studerende prøver at forbinde teksten til den virkelige verden eller til det, hun tidligere har læst og forsøger således aktivt at få teksten til at give mening. Studerende, der benytter sig af denne strategi, 'angriber', om man så må sige, teksten ud fra en holistisk strategi og ser teksten som et middel til at forstå forfatterens budskab.

Anderledes er det med studerende, der benytter sig af overfladestrategi. Her er den studerende ikke optaget af at forstå, men kun af at udføre kravene til den stillede opgave. Samtidig er det karakteristisk, at den studerende forvrider opgavens struktur.

Ifølge Ramsden er overfladestrategien karakteriseret ved, at den studerende:

- " fokuserer på 'tegnene'(dvs. ordene og sætningerne i teksten, eller uden tankevirksomhed på den formel, som skal anvendes til at løse problemet).

- fokuserer på dele af opgaven, som er uden forbindelse med hinanden.

- udenadslære, informationer til brug for prøver

- forbinder facts og begreber uden at reflektere over det.

- undlader at sondre mellem regler og eksempler.

- behandler opgaven som noget, der er pålagt udefra.« (Ramsden,1999, s. 64).

Der er altså her, i modsætning til dybdestrategien, tale om en ydre vægtning: F.eks. fokus på eksamenskrav. 
Ligeledes opleves den viden, der skal tilegnes, som isoleret fra hverdagens virkelighed.

Både Bakhtins overvejelser mht. dialog og læring og Dysthes tanker vedrørende det at forholde sig dialogisk til autoritative diskurser korrelerer til Ramsdens studier af dybdestrategier og dybdelæring. Det at forholde sig dialogisk til et fagligt indhold bidrager til at uddrage et personligt meningsindhold til f.eks. en skreven tekst. Det kan bidrage til udvikling af metakognitive kompetencer og kan således ifølge Ramsden facilitere dybdelæring.

\section{Biggs SOLO-taksonomi}

I bestræbelsen på at udvikle undervisning, hvor studerende har mulighed for at opnå et intenderet læringsresultat på så højt kognitivt niveau som overhovedet muligt, har Biggs udarbejdet en kvalitativ taksonomi, SOLO-taksonomien, der kan hjælpe med at få præciseret og defineret læringsresultatet for undervisningen. SOLO står for Structure of the observed learning outcome. Taksonomien er baseret på studier af studerendes lærings- eller forståelsesresultater inden for forskellige akademiske områder. Ifølge Biggs (2003) viser studerendes læringsresultater de samme stadier af øget strukturel kompleksitet. På baggrund af denne indsigt er SOLO-taksonomien udviklet. Taksonomien er et redskab til at beskrive forskellige niveauer af de studerendes forstålse: » The intended learning outcomes" (ILO). (Biggs, 2003).

Vurderingssystemet går lige som hos Ramsden ud fra en skelnen mellem overfladelæring og dybdelæring. Biggs påpeger, at der forekommer to former for ændringer i forhold til den studerendes læring: Kvantitative ændringer, hvor det drejer sig om forøgelse af mængden af detaljer i de studerendes svar (som svarer til overfladelæring) og kvalitative ændringer, som svarer til dybdelæring, hvor detaljerne integreres i en sammenhængende helhed, og hvor den studerende selvstændigt skaber en indsigt i dybere sammenhænge og danner egne meningsstrukturer i forhold til indholdet.

Taksonomien består af fem niveauer: Det præstrukturelle niveau, det unistrukturelle niveau, det multistrukturelle niveau, det relationelle niveau og det udvidede, abstrakte niveau. De tre første niveauer henføres til/karakteriseres som overfladelæring og de to sidste som dybdelæring. Hvert højere niveau indeholder de lavere niveauer plus noget mere. Taksonomien beskriver således et hierarki, hvor hvert niveau er fundamentet, hvorpå videre læring bygger.

\section{Læseloggens resuméfelt}

I arbejdet med læseloggen er tanken, at den studerende starter med at forholde sig holistisk til teksten, for derefter at relatere tekstens dele til helheden. Derfor startes der i resuméfeltet med en skriftlig sammenfatning af tekstens hovedbudskab, forfatterens ide med teksten, hvorefter den studerende arbejder med teksten som et 'middel' til at forstå/understøtte budskabet.

Dette arbejde skulle gerne hjælpe den studerende med at lære at skelne mellem principper og eksempler, undersøgelsesmaterialer og konklusioner og mellem kernepunkter og sekundære detaljer.

I resuméfeltet arbejdes der altså med at holde fokus på tekstens nøglebegreber og begrundelser. Herigennem læres det, som Ramsden betegner: At "Fokusere(r) på, 'hvad der betegnes'(dvs. forfatterens resonnement eller de begreber, der er relevante for at lose problemet) «. (Ramsden, 1999, s. 64)

\section{Læseloggens perspektiveringsfelt}

Hensigten med at arbejde med læselog er først og fremmest at understøtte den studerendes aktive konstruktionsproces og den studerendes dialogiske behandling af et stof.

I perspektiveringsfeltet gives der mulighed for at personliggøre indholdet ved, at den studerende relaterer den nye viden til tidligere erhvervet viden og hverdagens erfaringer. Det nye stof gives, som Ramsden udtrykker det, en indre vaegtning (Ramsden, 1999). I arbejdet med perspektiveringsfeltet gives der mulighed for, at ny kundskab og struktur kan integreres med tidligere lært og lagret kundskab. Med andre ord inviteres den studerende her til en indre dialog med teksten. Den dialog, som Bakhtin og Dysthe $(1995 ; 2003)$ anser som grundlag for en forståelse af stoffet og som grundlag for at koble det ydre med det indre. En dialog, som gerne skulle facilitere de personlige konstruktionsprocesser i forhold til allerede erfaret viden og dermed bidrage til dybdelæring, hvis man ser det i forhold til Ramsdens læringsstrategier, og udvikle tænkning på det relationelle og det udvidede abstrakte niveau, hvis man ser det $\mathrm{i}$ forhold til Biggs SOLO-taksonomi (Biggs, 2003).

\section{Distribueret kognition}

Distribueret kognition handler om, at der findes kognitive processer, der må tilskrives et fællesskab. Tanker, som hver enkelte person ikke ville have fundet på uden for fællesskabet, opstår i fællesskabet. Diskussioner i grupper kan derfor fore til indsigter, som ingen af deltagerne mente sig i besiddelse af for deltagelsen $\mathrm{i}$ gruppen (Rasmussen, 2005, s.210).

Læseloggens perspektiveringsfelt tydeliggør, at de studerende kan og ved noget forskellig og derfor også har mulighed for at perspektivere, forstå, forklare og udvide den samlede gruppes forståelse af stoffet på meget forskellig vis på baggrund af tidligere erfaret viden.

Perspektiveringsfeltets synliggørelse af denne forskellighed, i følgeskab af en fælles bevidsthed om muligheden for distribueret kognition, kombineret med en bevidsthed fra underviserens side om at udnytte 
deltagernes forskellige viden, kan føre til en bredere eller dybere helhedsforståelse af emnet, til distribueret kognition, og kan yderlige bidrage til f.eks. en kreativ forståelse i Bakhtinsk forstand. Det er bl.a. når de studerende oplever dette, at de kan se meningen med og finde motivation til at udarbejde læselogs.

\section{Forberedelse med læselog tager tid}

Der er ingen tvivl om, at arbejdet med læselog er tidskrævende for de studerende: At skrive og tænke, i modsætning til 'blot at læse teksten' tager tid. Der er heller ingen tvivl om, at mange studerende (måske de samme studerende som plejer at arbejde med tekster vha. overfladestrategi (Ramsden, 1999)) også synes at have svært ved at arbejde med og se nytten af perspektiveringsfeltet. At nedskrive hovedbudskab, nøglebegreber og hovedargumentationer i resuméfeltet kan opleves som svært men kan til nød ses som relevant i forhold til senere brug/repetition. Men perspektiveringsfeltet opleves af nogle studerende som irrelevant, hvis ikke disse studerende oplever episoder med distribueret kognition eller brug af indholdet i perspektiveringsfeltet enten i studiegrupperegi eller i holdundervisningsregi.

Mine erfaringer ${ }^{2}$ er, at hvis det skal lykkes at fă de studerende til at udarbejde læselogs, så må de bagvedliggende tanker omkring læselog i den grad ekspliciteres, og ofte også flere gange, samtidig med, at indholdet, specielt i perspektiveringsfeltet, reelt bruges i undervisning eller studiegrupper. Derudover er det min erfaring, at det at gøre de studerendes læselog til en form for fælles eje ved at lægge dem ind på f.eks. blackboard/studienet kan hjæelpe de studerende, der har svært ved at fange ideen med perspektiveringsfeltet.

\section{Undervisning med udgangspunkt i læselog}

Læseloggen kan udover at invitere den studerende til en indre dialog også bruges i dialogisk undervisning og dermed facilitere mere aktiverende undervisning, der reelt baserer sig på de studerendes indsats.

Universitetsadjunkters erfaringer ${ }^{3}$ med brug af læselog $\mathrm{i}$ undervisningen peger på, at det kan være svært at få de forskellige læselogs til at blive omdrejningspunktet for undervisningen, således at muligheden for distribueret læring er til stede og således, at der f.eks. også bliver tale om reelle dialoger i undervisningen (også ved f.eks. autoritative diskurser).

Jeg har fra undervisning på mellemlange uddannelser erfaring med, at muligheden for dette er større, hvis man som underviser bruger perspektiveringsfeltet $\mathrm{i}$ de individuelle læselogs (eller udvalgte læselogs) som udgangspunkt for undervisningen.

Undervisningen kan f.eks. indledes med, at de individuelle punkter i perspektiveringsfeltet bliver diskuteret og prioriteret $\mathrm{i}$ grupper med henblik på efterfølgende drøftelse på holdet.
Det kræver dog et forholdsvis trygt og tillidsfuldt undervisningsmiljø, idet nogle studerende kan have svært ved i offentlighed at 'udstille' deres forskellige viden og erfaring inden for feltet, deres interessefelter og ikke mindst deres manglende forståelse af indhold. Hvis undervisningsmiljøet er i orden, hvis de studerende har forstået de bagvedliggende tanker omkring læselogs og hvis underviseren reelt tager udgangspunkt i de studerendes ønsker og behov (ud fra perspektiveringsfeltet) er det min erfaring, at de studerende gerne vil tage ansvar for undervisningen gennem udarbejdelse af læselog med efterfølgende prioritering af diskussions- og afklaringspunkter til undervisningen.

For underviseren ligger udfordringen $i$ at turde stole på sin egen faglige kompetence, sit faglige overblik, evnen til at bevare en rød tråd i undervisningen og 'nå stoffet', når udgangspunktet nu tages i den studerendes perspektiv.

Hvis man som underviser er bekymret for, om dialogen er 'relevant nok' eller er på et tilpas fagligt niveau, og hvis man som underviser trods alt gerne vil sikre sig, at hovedbudskaber, nøglebegreber, nøgleargumentationer er præsenteret på en eller anden måde, kan der være perspektiv $i$, at underviseren afslutter lektionerne med et hurtigt resumé eller præsentation af 'pointerne' gerne $\mathrm{i}$ form af powerpoint, som efterfølgende kan lægges ud på holdets website/konference. Et sådant resumé kan dels fungere som opsamling, som feedback og som yderligere bidrag til de studerendes egen personlige læselog.

\section{Hurtig feedback}

Der kan også arbejdes konstruktivt med læselogs i studiegrupper. Et studiegruppearbejde med fokus på læselog kan enten tage udgangspunkt i individuelt udarbejdede læselogs eller basere sig på udarbejdelse af en fælles gruppelæselog. I gruppedrøftelserne vil hver enkelt studerende hurtigt gennem dialogen med medstuderende kunne fă feedback på, om de har forstået tekstens konklusion eller hovedbudskab. De kan hurtig få feedback på, om de har fået fat i nøglebudskaber, argumentationer og begreber, og netop den hurtige feedback anses som væsentligt for effektive læreprocesser (Biggs, 2003; Brown m.fl., 2005; Race, 2005; 2008). Derefter vil der være mulighed for, at deltagerne kan drøfte, analysere, relatere, reflektere og perspektivere teorien eller problemfeltet ud fra det, hver enkelt finder relevant i perspektiveringsfeltet. Gruppedrøftelsen af deltagernes forskellige perspektiveringsfelter, eller bidrag til et fælles perspektiveringsfelt, kan hjælpe til udvikling af forskellige holdninger og meninger, til udvidet forståelse og til yderligere perspektiveringer og konkretiseringer.

Der kan være perspektiv $i$, at underviseren i relation til studiegruppearbejde på klassebasis opsummerer, systematiserer og laver en yderligere refleksion mhp. 
konsolidering af stoffet på baggrund af få udvalgte punkter fra grupperne. Fordelene ved dette kan være, at de studerende endnu engang får mulighed for hurtig feedback både mht. det faktuelle indholdsmæssige men også i forhold til yderligere menings-/tænkningsgenerering og -perspektivering.

Gruppesamtalen ud fra de forskellige læselogs og den efterfølgende, opfølgende samtale og opsummering på klassebasis kan ligeledes facilitere det, som Bakhtin kalder for kreativ forståelse, altså mening og indsigt, udviklet vha. gensidighed, intersubjektivitet og forhandling (Dysthe, 2003).

\section{Afrunding}

Ud fra ovenstående skulle det gerne fremgå, at der ligger nogle muligheder i periodevis at få de studerende til at arbejde med læselog for efterfølgende at bruge læseloggen som udgangspunkt for undervisningen.

Arbejdet med læselog giver ikke blot flere studerende mulighed for dybdelæring og kreativ forståelse af et stof eller tema. Det giver også mulighed for at basere undervisningen på de studerendes indsats uden for undervisningen og etablere reel dialog med mulighed for større forståelse og perspektivering af stoffet.

Både ved at arbejde med læselog i studiegrupper og i forberedelse til holdundervisning, der tager udgangspunkt i læselogs, făr den studerende mulighed for at opleve, at hendes viden, færdigheder og erfaringer kan bidrage til og har betydning for en udvidet forståelse af et fagligt stof.

Som nævnt kræver læselog langt større forberedelse fra den studerendes side, hvorfor der er perspektiv $i$ at bruge læselog periodevis, gerne i starten af et semester, med henblik på at den studerende oparbejder en rutine med hensyn til denne måde at tilegne sig stof.

Akilleshælen er selvfølgelig ud fra den studerendes perspektiv tidsforbruget og ud fra underviserens stoftrængslen og underviserens trang til at have kontrol over situationen og nå stoffet. Dette må ses og vurderes i forhold til muligheden for dybdelæring, større motivation og engagement og udvikling af metakognitive kompetencer hos den studerende.

\section{Referencer}

Biggs, J. (2003). Teaching for Quality Learning at University. Second Edition. Society for Research into Higher Education and Open University Press.

Brown, S., \& P Race \& B. Smith (2005). 500 Tips on Assessment: 2nd ed. Routledge Falmer.

Danmarks statistik. Uddannelsesboom på ti år. Nyt fra Danmarks statistik. Nr. 424 24/9 2010 (www. Dst.dk).

Dysthe, O. (Red.).(2003). Dialog, samspil og laring. Klim

Dysthe, O. (1995). Det flerstemmige klasserum. Skrivning og samtale for at lace. Klim.

Illeris,K.(2006). Laring. Roskilde Universitetsforlag.

Race, P. (2005). Making Learning Happen. London: Sage.

Race, P. (2008), 24 Hours Feedback.Issue 1 of the ALT Incubator Journal, Leeds Metropolitan University.

Ramsden, P. (1999). Strategier for bedre undervisning. Gyldendal.

Rasmussen, Jens.(2005). Undervisning $i$ det refleksivt moderne. Hans Reitzels Forlag.

Sørensen, B. (2001). Litteratur forståelse og fortolkning. Alinea.

Vygotsky, L.S. (1997). The History of the Development of Higher Mental Functions. (Bind 4) NewYork and London: Plenum Press.

Vygotskij, L.S. (2001). Tenkning og tale. Gyldendal akademiske forlag.

\section{Noter}

1 Her gør Dysthe rede for en model for læring ud fra Bakhtins teorier, som hun kalder social-interaktiv og dialogisk

2 som hovedsagelig er baseret på studerende på mellemlange videregående uddannelser men også på universitetsadjunkters udviklingsprojekter i deres adjunktpædagogikum ved Syddansk Universitet

3 Erfaringer jeg er stødt på gennem supervision og pædagogiske udviklingsprojekter i adjunktkvalificeringsforløb på Syddansk Universitet. 